\title{
A DEFENCE OF THE CLICHÉ ${ }^{1}$
}

\author{
ADOLPHE HABERER \\ Université Lumière-Lyon 2
}

\begin{abstract}
A sure thing is that clichés have a bad reputation. Trying to define the cliché as a linguistic or stylistic category, however, leads to all sorts of difficulties, as we seem to be dealing with "matters as imprecise as the shape and size of a cloud or the beginning and end of a wave". Following the example of Louis MacNeice who once wrote a "Homage to Clichés", in this paper I will take the defence of the cliche and show that in the terms of a (Lacanian) problematics of the subject's enunciation it has its own function and significance.
\end{abstract}

"ce cour parlant que nous appelons l'inconscient" Jacques Lacan (in Kaufman 1993: 395)

Samuel Godwin (1948), the Hollywood cinema magnate, is reported to have once said to his team of script-writers: "Let's have some new clichés!". This raises the question of whether one can "make it new" when dealing in clichés, or be at all original when dealing with clichés - as I will be doing here -, bearing in mind everything that has been said or written on the subject. Perhaps, the only proper way to address the cliché is, as we shall see presently, to follow the example of Louis MacNeice, who composed a "Homage to clichés", and write up something that would be both an illustration and a defence of the cliché, a discourse from which anything new or original would be eliminated, leaving only what falls into the categories of the banal, the commonplace, the ready-made formula, the

1. A prior version of this article was published in British and American Studies VIII: 199-214, 2002.

2. "that speaking heart, which we call the subconsious" (my translation). 
stereoptype, and other such expressions that belong to everybody, refer us to the fundamental principle of the common ownership of the means of expression those worn out and still ready-to-wear phrases, always available, off the peg, hackneyed phrases, as they say in English, the word hackney having successively been used to mean a horse kept for ordinary riding, a horse kept for hire, a coach for hire, a common drudge and a prostitute. It is not easy to wear the mask of the cliché-monger for any length of time, however, and J. A. Cuddon (1979: 125), who tries to put together a whole string of clichés in his Dictionary of Literary Terms, is soon forced to come to a stop, without having even managed to be really funny:

When the grocer, who was as fit as a fiddle, had taken stock of the situation, he saw the writing on the wall, but decided to turn over a new leaf and put his house in order by taking a long shot at eliminating his rival in the street - who was also an old hand at making the best of a bad job.

On the other hand, if we try to develop a serious reflection on the cliché, we soon realize that the first difficulty lies in the absence of any clear, easy, wellaccepted definition of the concept of cliché, and also in the existence of all sorts of terms, most of the time loosely given as equivalent to the cliche - the catch phrase, the slogan, the set expression and the locus communis more or less completing the list begun with the stereotype, the ready-made formula, the hackneyed phrase, the commonplace. So, I will first set myself the task of giving a definition of the cliché.

\section{A DEFINITION OF THE CLICHÉ}

As cliché is a French word, it is fair to look up its meaning in the Littré, still a useful reference book today. If you do so, you will find that a cliché is "une planche en relief obtenue par le clichage" by workers called clicheurs working in a clicherie, and that the verb clicher, itself a form of the very common cliquer (to click), which probably has an onomatopoeic origin. The OED confirms the origin of the word cliché as the past participle of the verb clicher.

The French name for a stereotype block [...]. Originally, a cast obtained by letting a matrix fall face downward upon a surface of molten metal on the point of cooling, called in English type-foundries "dabbing".

Both the cliché and the stereotype (from the Greek, meaning literally "solid type") originally refer to techniques used by printers. The latter is described in the $O E D$ as a process of printing with a solid plate "cast from a papier-mâché or 
plaster mould taken from the surface of a form of type", and was invented in France towards the end of the 18th century by Firmin Didot. Both are descriptive of a mechanical process allowing the printing of an endless number of identical copies of the same form, or body of type. With the invention and development of photography, the word cliché was then used in French (not in English, though) to mean the transparent photographic image showing dark areas as light and light areas as dark, from which as many identical prints can be obtained as necessary.

When was the word cliché first used metaphorically? According to Le Nouveau Petit Robert, the figurative and pejorative meaning of "ready-made idea or expression too often used" appears in France in 1869. As for English, the OED gives 1892 as the date of the first use of cliché meaning "a stereotyped expression, a commonplace phrase, also a stereotyped character, style, etc". The use of cliché in English seems to have taken some time before it became common usage: the second edition of The King's English (1908) published by the Fowler brothers, does not mention it, whereas in A Dictionary of Modern English Usage (Fowler 1926), it appears among the technical terms, meaning "stereotype block", a French name used to name hackneyed phrases.

There is an innocent question which I would like to ask at this point, for which I have no ready answer. Why is it that the English borrowed the word cliche from the French, and only in its pejorative meaning? Was there no good native Anglosaxon alternative available? The technique of stencilling used from the 18th century and the word stencil (by the way ultimately derived from the French étincelle) could have served the purpose, and though Webster's Third New International Dictionary gives for stencil the figurative meaning of "uninspired or insipid repetition usu. [ally] of an original idea or plan", not so the OED. ${ }^{3}$ With no ill-feeling, I would like to suggest that the very successful borrowing of the word cliche by the English admirably exemplifies a certain way of enriching the national vocabulary by using foreign words when they refer to indecent, sinful, reprehensible, or merely objectionable practices, thus implying that such practices are typically foreign, preferably French, unknown among true-born Englishmen. Thus cliché would fall into the same category as faux-pas and coup d'Etat, together with double entendre, billet doux, négligé and ménage à trois, such expressions all implying more or less dubious situations and a lack of straightforward honesty. Let not a Frenchman, however, cast the first stone at the English! All nations are guilty of the same modes of lexical enrichment at the expense of their neighbours. But there remains an

3. The OED mentions poncif as French and meaning "stereotyped or conventional literary ideas, plot, character, etc". The technique of the poncif in art was similar to that of the stencil. 
undeniable French connotation attached to the very concept of cliché in English, as though it were the result of a continental influence unduly allowed to spread on British soil. A quotation from Swift's "Letter to a Young Gentleman" (Swift 1948: 68), however, will show that the thing was already rampant in England long before the word was imported:

Two things I will just warn you against: the first is the Frequency of flat, unnecessary Epithets; and the other is the Folly of using old threadbare Phrases, which will often make you go out of your Way to find and apply them; are nauseous to rational Hearers, and will seldom express your Meaning as well as your own natural Words.

Let us return to our sheep - if I may use a ready-made phrase adopted from the French -, that is to say to the definition of the cliché. Having checked a number of reference books, I have come to the conclusion that definitions vary a good deal with authors, and that all possible gradations are to be found between two extremes: on the one hand the loose, extensive definition, with which almost anything can be treated as cliché; on the other the restrictive narrow definition with which the cliché becomes a rare bird indeed.

Extensive definitions sometimes boil down to the simple notion of "repeated discourse", but this includes proverbs, quotations, and all proverbial or otherwise set collocations (Delas \& Filliolet 1973: 96-99). Eric Partridge, who set himself the task of making a detailed catalogue of clichés in his Dictionary of Clichés (1978) found that they fell into four categories, i.e. "idioms that have become clichés", "other hackneyed phrases", "stock phrases and familiar quotations from foreign languages" and "quotations from English literature", a picturesque classification which no linguist today would take seriously. Permyakov's definition of clichés (1979) as "set word-combinations which are reproduced in a form fixed once and for all", though more sober, is still quite as extensive as the other two.

Extensive definitions can even go further and pass on from the level of expression (plan de l'expression) to the level of content (plan du contenu). For Michèle Aquien (1993: 34), the cliché is "a stereotyped image, also called poncif, or lieu commun". The same author adds that "the characteristic banality of the cliché can lie as much in the image as in the idea". In a very instructive study of the locus communis of the swan, Didier Alexandre (in Plantin 1993: 46) speaks of "formal and thematic clichés". And as we have seen earlier, in both the OED and Le Nouveau Petit Robert the notion of cliché can very extensively be applied to ideas, characters, and situations. 
If I turn now to the restrictive definitions of the cliché, I think that the most restrictive are those of the linguists for whom the cliché has no pertinence whatsoever, and their strict attitude towards the cliché is made quite clear by the fact that they do not even mention its existence as fait de langue. To take one single example, the word does not appear in Ducrot and Todorov (1972) though their book is the sort of reference book that aims at covering all the many fields related to language.

In some other cases, linguists will acknowledge the pertinence of the concept of cliché, but will give it a very strictly limited use. I have in mind Arnaud and Moon (in Plantin 1993: 37-38) and their study of what they call "proverbial clichés", structures leaving one or several vacant slots into which lexical elements can be inserted, and referring to the form of a canonical proverb - for example, "Too many X's spoil the Y", with reference to the proverb "Too many cooks spoil the broth", allows the production of proverbial clichés, such as "Too many jokes spoil the fun", "Too many guests spoil the party", or ... "Too many lectures spoil the conference", etc.

Another interesting attempt at defining the cliché is the one proposed by Gerstenkorn (in Plantin 1993: 37-38) who makes a clear distinction between the stereotype, which in rhetoric comes under inventio, and the cliché, which comes under elocutio. Thus "the ruler's inflexible authority" will be considered as common motif, or topos, or stereotype, and "the iron hand" (with or without its "velvet glove") as a cliché, a fixed discursive unit, or lexicalized metaphor. A similar distinction is made by Andrée Chauvin (in Plantin 1993: 27) between the logical, ideological, argumentative level of the topos, or locus communis, and the properly linguistic plane of literally constituted syntagms, where she further distinguishes verbal stereotypes and clichés, the latter being lexicalized tropes.

In the taxonomic quarrel over the definition and classification of clichés, I have no authority or competence to decide who is right and who is wrong. But I wish to say that this last restrictive definition of the cliché suits me, as it corresponds to my own practice as teacher of poetry and poetics, though I prefer to speak of "poetic images" than of tropes. The expression "poetic image" brings together the order of the signifier and that of the signified, the poet's activity as a maker working with words and the imaginary representation which is the effect of that making. One further advantage of the notion of "poetic image" over that of "lexicalized trope" is that it leaves out those dead tropes that have lost their power to produce imaginary representations, unless they do so absurdly, as in the case of a catachresis (meaning "improper use" in Greek) - for example when carried away by enthusiasm one speaks of "a virgin country, pregnant with possibilities..." Finally, the expression 
"poetic image" refers the cliché to both word and image, namely to the original technical use of the word cliché among the first unchallenged legitimate clichémongers - I mean printers and photographers.

At this point, having found a definition of the cliché that I find precise enough and therefore operative, I must however add that there is still one essential element missing to it if I want to account for the fact that each of us has an intimate ready knowledge of what a cliché is. In the same way as "to call a spade a spade" requires a certain experience of what a spade is, as Oscar Wilde well knew, to call a cliché a cliché requires an experience of the poetic, a familiarity with the uses and abuses of language, a capacity to recognize recurrent images, and a tender susceptibility to the sense of déjà vu they engender. In other words, there is no cliché out of the context of its reception. There is no cliché without subjectivity being brought into play. Which probably accounts for the linguists' reticence towards the cliché, as many linguists, though not all, prefer to deal with problems of language outside the context of interlocutory discourse.

\section{THE CLICHÉ AND ENUNCIATION}

There is no cliché without a judgement of value, and that judgement is usually negative. "Cliché!" used to appear red-pencilled in the margins of my schoolboy's compositions and essays, at the time when I was making my first attempts at writing "with style". An image is perceived as a cliché only from someone's point of view, according to his or her taste, preferences, and prejudices. There could even be a socio-linguistic approach to the question, and the appreciation of clichés might well be shown to depend upon age, class, education and gender, etc. The directions I now want to follow, however, are not those of sociolinguistics, but two directions related to the problematics of enunciation, my starting points being: firstly, the fact that with the cliché an act of speech is always explicitly or implicitly involved, that an image is pronounced a cliché, and the pronouncement made within the context or framework of an interlocutary situation; secondly, the fact that the cliché is always referred to an axiology - i.e. the application of a scale of values.

With regard to interlocution, the "cliché effect" can only be experienced by the addressee of a message received from some addresser. The well-known description Roman Jakobson gives of verbal communication must be modified, however, in order to show that interlocution is also at work in the silent reading of a written text, the reader being led to lend his voice to and assume the enunciation of what he is reading, so that when I read a love poem, for instance, 
I am at the same time speaking it and listening to it, addressing myself as an other, the inner forum of my subconscious (which we call "le for intérieur" in French) being the locus of the interlocutary rapport in which $I$ and you do not refer to identities but to enunciatory positions. So, when I read:

Shall I compare thee to a summer's day?

Thou art more lovely and more temperate:

Rough winds do shake the darlings buds of May,

And summer's lease hath all too short a date

I am at once reader and listener, addresser and addressee, lover and beloved, and need not know anything of Shakespeare's love life to become involved in the poem's enunciatory operations. To put it more bluntly, it takes at least two to have a cliché, and I can be those two at the same time. And one of the two must be in the position of reader, or listener, expecting novelty and originality. The "cliché effect" indeed springs from a sense of disappointment and frustration, and do not tell me, by the way, that you have never been both the embarrassed author and the severe judge of your own clichés when writing a poem, a love letter or... a conference presentation!

This explains why the "cliché effect" is best experienced by those whose role, or job, or pleasure, is to evaluate and criticize. Teachers of course are, or think they are, great experts in clichés, and this goes too for literary critics. What I would like to develop, however, is the idea that the "cliché effect", when experienced, interrupts what had been established as an interlocutory exchange between addresser and addressee. When I say or think "Cliché!" to what I hear or read, the other as subject of enunciation I was listening to is so to speak disqualified as subject, reduced to his utterance (or énoncé), and that utterance assessed as worthless and rejected as cliché. The addresser disappears as subject. Instead of lending my ear to what is being said of the other's truth through what he or she is trying to say, I stop listening. I am deaf to the other's coeur parlant, Lacan's "speaking heart", desirous though that heart is to speak out, sometimes to speak volumes - "voluminous" as it can be, like Hopkins' "heart in hiding". The woman who hears clichés in the passionate declarations of her lover has already decided that she does not love him. To use a metaphor which is itself a cliché among soccer fans, the cliché is the red card you take out of your pocket, as self-appointed arbiter elegantiae, the other being sent off, having to shut up and leave the field.

Such an exercise in axiology, I would like to suggest, manifests an obscure, mostly subconscious, desire to dismiss the other (to give him the axe), by reducing him to his poor, clumsy words. It corresponds to the imaginary triumph 
of the self. It is easy to perceive the arrogant self-sufficiency and self-complacency of the self-appointed guardians of good taste, and their jouissance in denouncing clichés. Take Rémy de Gourmont (in Riffaterre 1971: 161), who belonged to the generation of the French symbolistes, for whom a cliché was "the expression of an anonymous brain and perfect intellectual servilism". ${ }^{4}$ Or take Eric Partridge (1969: 73), who writes:

A cliché is an outworn commonplace; a phrase [...] that has become so hackneyed that scrupulous speakers and writers shrink from it because they feel that its use is an insult to the intelligence of their auditor or audience, reader or public.

Any axiological system, however, is reversible. This is well-known. Even Partridge's superior airs and severity sounds a little forced and excessive, the more so when one realizes that in order to publish his Dictionary of Clichés he must have spent years collecting them, and a collector cannot but love the things he collects. So, it is not unimaginable to find true connoisseurs of clichés, ready (like me) to write a "Defence of Clichés". Georges Perec was one, and with La Cantatrice chauve, Eugène Ionesco certainly gave the cliché its "lettres de noblesse". But here I would like to turn to the poet Louis MacNeice and consider his "Homage to Clichés" (MacNeice 1966: 59-60). Here is the beginning of the poem:

With all this clamour for progress

This hammering out of new phases and gadgets, new trinkets and phrases I prefer the automatic, the reflex, the cliché of velvet.

The foreseen smile, sexual, maternal, or hail-fellow met, The cat's fur sparking under your hand And the indolent delicacy of your hand These fish coming in to the net I can see them coming for yards The way that you answer, the way that you dangle your foot These fish that are rainbow and fat One can catch in the hand and caress and return to the pool.

So five minutes spent at a bar

Watching the fish coming in, as you parry and shrug

This is on me or this is on me

Or an old man momentously sharpens a pencil as though

He were not merely licking his fur like a cat -

The cat's tongue curls to the back of its neck, the fish swivel round

4. My translation. 
by the side of their tails, on the abbey the arrows of gold

On the pinnacles shift in the wind -

This is on me this time [...] (lines 1-19)

I quite readily admit that the meaning MacNeice gives here to the word cliché is a good deal more extensive than the one I said I preferred. ${ }^{5}$ But what he says of the "cliché of velvet" in a world in constant flux, filled with the sense of impending gloom - the poem was written in December 1935 - can mutatis mutandis be applied to the cliché as lexicalized trope or familiar poetic image. MacNeice will thus help me on my way, in my effort to understand why, in certain circumstances, clichés can be a source of emotion and happiness, so that the cliché cannot be reduced to a mere manifestation of bad taste and bad style. Let us follow MacNeice (1966) a little further:

What will you have now? The same again?

[...]

A gin and lime or a double Scotch -

Watch the response, the lifting wrist the clink and smile

The fish come in, the hammered notes come out

From a filigree gothic trap.

These are the moments that are anaplerotic, these are the gift to be accepted

Remembering the qualification

That everything is not true to type like these

That the pattern and the patina of these

Are superseded in the end. (lines 26-36)

It appears that for MacNeice the cliché implies repetition (the proper cliché is "true to type", like the stereotype) and long wear ("the pattern and the patina"), and this can give it the value of a sort of epiphany, of an anaplerotic gift (anaplerosis being the filling up of a deficiency) that momentarily fills up the lackto-be (Lacan's manque-à-être), before the final catastrophe. It can thus be argued that the cliché has to do with the subject's desire at the very point where desire is articulated upon language, which means that the cliché has to do with the structure of Lacan's parlêtre, or "speaking-being", man or woman as belonging and subjected to the order of language.

5. In "Experience with Images", MacNeice (1987: 163) writes: "In some poems of this type I have used a set of basic images which crossfade into each other; thus in 'Homage to Clichés' (1935) clichés (by which I meant the ordinary more pleasant sense-data of the sensual man) are imaged by fish coming in to a net, by the indolent self-contained behaviour of cats, by the chiming of bells (where the bell itself does not move), and by the ordering of drinks ('the same again') at a bar". 


\section{THE CLICHÉ AND THE STRUCTURE OF THE PARLÊTRE}

In "Politics and the English Language" George Orwell (1970: 159) declares that there are newly invented metaphors, metaphors that are technically dead, and that between those two categories there is "a huge dump of worn-out metaphors". These worn-out or "dying metaphors" - in Orwell's list you find "toe the line", "ride roughshod over", "no axe to grind", "grist to the mill", "fishing in troubled waters", "swansong", "hotbed" - are in fact clichés, for ever dying but still alive in political discourse. Christopher Ricks (1984: 250) makes a similar remark when he writes that clichés are "phrases which are dead but won't lie down". Clichés are indeed extraordinarily resistant, and the capacity they have to survive may well mean that they have an irreplaceable function, for in their humble paltry way they bring into play the Lacanian categories of the real, the symbolic, and the imaginary, bound together (the metaphor is to be found in John Donne's "The Extasie") into "that subtile knot, which makes us man".

The way in which clichés can bear upon or refer to the real is well illustrated in the second part of MacNeice's poem (1987: 163), where the real is represented by "the imminent pealing of bells (where the bell does move), the tenor bell being equated with a stone Rameses about to move his sceptre and dismiss the productions of Time"”:

Never is the Bell, Never is the Panther, Never is Rameses

Oh the cold stone panic of Never -

The ringers are taking off their coats, the panther crouches

The granite sceptre is very slightly inclining

As our shoes tap against the bar and our glasses

Make two new rings of wet upon the counter

Somewhere behind us stands a man, a counter

A timekeeper with a watch and a pistol

Ready to shoot and with his shot destroy

This whole delightful world of cliché and refrain -

What will you have, my dear? The same again? (lines 69-82)

Repetition, at work in the cliché, may be interpreted as a symptom. It is significant of desire's insistence and failure to take the real in the nets of discourse. In a famous formula, Lacan (1975: 53) said that "the universe is a flower of rhetoric", by which he meant that all knowledge, constitutive of the cohesiveness of the universe which we inhabit, is but a discursive construct from which the real, as such, is forever absent. The cliché, as lexicalized trope, is like a nodule, a concretion, a cyst in the system of language. It speaks to us insistently of our failure to speak the impossible real. With clichés, something can always be heard of that failure. 
Now if you ask me what it is that there is no ultimate knowledge of, what it is that cannot be said of the real, I will answer by quoting three lines from "Sweeney Agonistes" (Eliot 1936: 127):

Birth, copulation, and death.

That's all the facts when you come to brass tacks:

Birth, and copulation, and death.

Encounters with the real more often than not occur in the event of birth, sex, and death, when we are left literally speechless, or experience the vanity of any discourse that might be equal to the event, that might speak the joy, the suffering, the jouissance, or the agony. Words fail us. And I believe that in such circumstances - for which religions have invented all sorts of rituals - the cliché proves very useful, serves its purpose, fills up the unbearable silence, starts up again the process of interlocution. Let me quote the first lines of another poem by Louis MacNeice (1966: 220), "Tam cari capitis", an elegy written after the death of his friend Graham Shepard, drowned at sea during the battle of the Atlantic, lost forever in "the dark backward and abyss of time" (The Tempest, I, 2, 50). The voicing of sorrow and of the sense of loss is here made possible by the quotation from Horace and the initial cliché:

That the world will never be quite - what a cliché - the same again Is what we only learn by the event When a friend dies out on us [...]

Often too, in the last stage of man's "strange eventful history", before "second childishness and mere oblivion", the "speaking heart" of old people can only mechanically repeat the same poor words, the same drivelling, the same poor ready-made phrases and clichés, and here again the cliché indirectly signifies something of the impossible real. Likewise, in his essay on aphasia, Roman Jakobson (1963: 58) notes that "only a few stereotyped, 'ready-made', expressions manage to survive". ${ }^{6}$ And I believe that in the clichés and stereotypes, sometimes repeated with such tiresome monotony by old people, something is to be heard of the first jouissance inscribed in the "speaking heart", when in its mother's arms the infant produced its first lallations.

As regards the imaginary, now, MacNeice makes no mistake in his praise of clichés and insists mostly on that function, associating as he does "the cliché of velvet" with those uneventful encounters in which the same meets the same, like

6. My translation. 
to like - "The foreseen smile, sexual, maternal, or hail-fellow-met". In the great store of language, the cliché is the most readily available item, ready-to-wear, fitting everybody, always second-hand and always as good as new. It allows everybody to go on his way, keeping to the beaten tracks of discourse, taking no chance, never risking too much of his parole. Clichés moreover characteristically render the images they convey almost transparent: little remains, for example, of the visual image conveyed by "it was raining cats and dogs" for native speakers of English, there being of course no cliché for learners of a foreign language, and foreigners being notably incapable of using clichés properly.

Which leads me to remark that the cliché is a great factor of social cohesiveness and identity, and most strikingly so in the case of social groups that are bound by the same type of discourse. As early as 1938, one Frank Whitaker (in Partridge 1969: 73), addressing a group of journalists, was busy denouncing the use of clichés when he remarked:

I have, however, heard their use in football reports defended on the ground that the public expects them, and would feel lost without them.

All readers of the sports pages of magazines and newspapers, whether they are soccer fans, or followers of the annual epic of the Tour de France, will perceive the relevance of this remark, which can very easily be transposed to other types of social discourse, that of the arts, of fashion, of politics or baute cuisine.

Finally, with regard to the category of the symbolic, I will say that the cliché also articulates the symbolic upon the categories of the real and of the imaginary, if only in a minor way. Among the definitions of the cliché which I have collected, one of my favourite ones is George Baker's metaphor of "a coin so battered by use as to be defaced" (in Partridge 1969: 1973), because money, like parole, is meant to circulate and be exchanged, and Jacques Lacan (1966: 251) - what a coincidence! also wrote that "la parole, même à l'extrême de son usure, garde sa valeur de tessère", the "tessera" in ancient Greece being a token, the tessera hospitalis, for example, being "a die broken between host and guest, and kept as a means of recognition" $(O E D)$. I would like to suggest that in the system of language the cliché is a poetic image "à l'extrême de son usure", and what it has lost in the way of novelty and piquancy is made up for by its familiar smoothness, MacNeice's "pattern and [...] patina", as with the worn handles of old tools or the threshholds of old houses, which look as if they remembered something of the hands and feet of the past. In a way, the cliché is like the intertext. In its great banality, it is the intertext

\footnotetext{
7. "parole, even when worn-out to an extremity, keeps its value as tessera" (my translation).
} 
of every Tom, Dick, and Harry, of the man in the street and of the nobodies of society. It is part of the intertext of our daily life, that great word-hoard of idioms, collocations, proverbs, and ready-made phrases, which belongs to nobody in particular because it belongs to everybody - “All men's, no man's, thine, mine”, to quote Louis MacNeice (1966: 313) again. If the first effect of the poetic, according to Robert Frost (in Scully 1966: 55), "lies in the surprise of remembering something I didn't know I knew", cannot we say that our "speaking heart" will also experience the same surprise, though ever so tenuously, in recognizing with every cliché something heard so many times and so many times forgotten?

\section{THE CLICHÉ AND MODERNITY}

As I come to my conclusion, I would like to suggest that in literature the concept of cliché is to be related to the notion of modernity. It is certainly significant that the cliché should have appeared in the late 19th century in the terminology used by critics and teachers, and that it should have so successfully formulated and cristallised an ill-defined notion during the decades marked by the advent of modernity in literature and the arts, with Ezra Pound "Make it new!" serving as a kind of motto. Before then, was ever Homer accused of having coined clichés with his repeated use of what is known as "Homeric epithets", such as (in their English version) "the wine-dark sea", "the rosy-fingered dawn", "swift-footed Achilles", "white-armed Hera", or "bright-eyed Athena" (Cuddon 1979: 309-310)? Were kennings - for instance "the whale-bath" or "the foaming fields" to refer to the sea -, those favourite stock phrases found in Old Norse skaldic verse and also in Old English poetry, ever criticized because they were repeated again and again? Was ever Petrarch condemned for having introduced the standard topo $i$ of love poetry and the conceits that were later imitated throughout Europe and are still very much alive, for instance, in the works of the English metaphysical poets? I believe that the aesthetics of novelty and originality, which is characteristic of our modernity, is at the origin of the cliché considered as an offence against good taste and style, in the same way as "poetic diction", which characterized the codified poetic language of the neo-classic 18th century, became offensive to Romantic ears after Wordsworth (1965: 246), in the Preface to the Lyrical Ballads, had denounced "arbitrary and capricious habits of expression [...] to furnish food for fickle tastes and fickle appetites" - all in the name of the new aesthetics of simplicity and naturalness.

At the heart of the concept of cliche in literature, the idea of the originality and creativity of the poet is very much part of the imaginary, self-complacent, narcissistic, hero-worshipping attitude we tend to have towards the process of writing. I will leave out all the theoretical work that has been done over the past 
forty years in the fields of linguistics, anthropology, and psychoanalysis, showing that we are more the subjects than the masters of language, and remind you that some of the great champions of our modernity were already long ago very much aware of the dangers of the great illusion entertained about the poet's originality. As early as 1919, T. S. Eliot (1951: 15, 17) declared in "Tradition and the Individual Talent", that "no poet, no artist of any art, has his complete meaning alone" and that "the progress of an artist is a continual self-sacrifice, a continual extinction of personality". And W. B. Yeats (1961: 522), at the end of his long career, once exclaimed: "Talk to me of originality and I will turn on you with rage. I am a crowd, I am a lonely man, I am nothing".

Even Joyce (1986: 140), often naively thought of as the original artist par excellence, has Leopold Bloom reflect "Never know whose thoughts you are chewing", and his Finnegans Wake, among many other things, can be presented as the result of a great process of linguistic and textual recycling. As Fritz Senn (1994: 195) puts it, Finnegans Wake "seems indefatigably to reassert the platitude that there is nothing new to impart". The Book of Ecclesiastes, full of the wisdom of Solomon, teaches that "there is no new thing under the sun", and this, like (almost) everything else, finds its way into Finnegans Wake (Joyce 1939: 493): "there is nihil nuder under the clothing moon".

Living as we do in the age of post-modernity, we know that fashions come and go, and the cliché, once mocked and condemned, probably deserves to be rehabilitated. This is what, following the example of Louis MacNeice, I have tried to do. Not that it constitutes a major issue. With or without clichés, what matters most in literary studies as in life is that, if we are attentive enough to what is being said in what we hear or read, something of the "speaking heart" will be heard, with its silences and intermittences, like another enigmatic "still small voice" (I, Kings, 19).

\section{REFERENCES}

Aquien, Michèle. 1993. Dictionnaire de poétique. Paris: Le Livre de poche. Cuddon, J. A. 1979. A Dictionary of Literary Terms. Harmondsworth: Penguin Books. Delas, D. and J. Filliolet. 1973. Linguistique et poétique. Paris: Larousse.

Ducrot, O. and T. Todorov. 1981 (1972). Encyclopedic Dictionary of the Sciences of Language. Transl. C. Porter. Oxford: Blackwell.

Eliot, T. S. 1936. Collected Poems 1909-1935. London: Faber.

Eliot, T. S. 1951. Selected Essays. London: Faber.

Fowler, H. W. and F. G. Fowler. 1908. The King's English. 2nd ed. Oxford: Clarendon Press. 
Fowler, H. W. 1926. A Dictionary of Modern English Usage. Oxford: Clarendon Press.

Godwin, Samuel. 1948. The Observer (October 24).

Jakobson, Roman. 1963. Essais de linguistique générale. Paris: Éd. de Minuit.

Joyce, James. 1939. Finnegans Wake. London: Faber.

Joyce, James. 1986. Ulysses: The Corrected Text. Ed. H. W. Gabler. London: Bodley Head.

Kaufman, P. 1993. L'Apport freudien. Paris: Bordas.

Lacan, Jacques. 1966. Écrits. Paris: Éd. du Seuil.

Lacan, Jacques. 1975. Le Séminaire, XX, Encore. Paris: Éd. du Seuil.

MacNeice, Louis. 1966. Collected Poems. London: Faber.

MacNeice, Louis. 1987. Selected Literary Criticism. Ed. Alan Heuser. Oxford: Clarendon Press.

Orwell, George. 1970. Collected Essays, Journalism and Letters, vol. 4. Harmondsworth: Penguin Books.

Partridge, Eric. 1969. Usage and Abusage. Hardmondsworth: Penguin Books.

Partridge, Eric. 1978. A Dictionary of Clichés. London: Routledge and Kegan Paul.

Permakyov, G. L., ed. 1979. From Proverb to Folk-Tale: Notes on the General Theory of Cliché. Moscow: Nauka.

Plantin, C., ed. 1993. Lieux communs, topoi, stéréotypes, clichés. Paris: Kimé.

Ricks, Christopher. 1984. The Force of Poetry. Oxford: Clarendon Press.

Riffaterre, M. 1971. Essais de stylistique structurale. Paris: Flammarion.

Scully, J., ed. 1966. Modern Poets on Modern Poetry. London: Fontana.

Senn, Fritz. 1994. "The Same Renew: Finnegans Wake as a Chamber of Echoes." Repetition. Ed. Andreas Fischer. Tübingen: Gunter Narr Verlag Tübingen.

Swift, J. 1948. "A Letter to a Young Gentleman." Irish Tracts 1720-1723 and Sermons. Oxford: Blackwell.

Wordsworth, William. 1965. Lyrical Ballads. Eds. R. L. Brett and A. R. Jones. London: Methuen.

Yeats, W. B. 1961. Essays and Introductions. London: Macmillan. 
